\title{
Customers' Responses to Employee Extra Attention
}

\section{Yoshimasa Kageyama, Albert Barreda}

Hospitality Leadership, Missouri State University, Springfield, USA

Email: YKageyama@MissouriState.edu, AlbertBarreda@MissouriState.edu

How to cite this paper: Kageyama, Y. and Barreda, A. (2019) Customers' Responses to Employee Extra Attention. Open Journal of Business and Management, 7, 59-69. https://doi.org/10.4236/ojbm.2019.71004

Received: October 19, 2018

Accepted: November 25, 2018

Published: November 28, 2018

Copyright $\odot 2019$ by authors and Scientific Research Publishing Inc. This work is licensed under the Creative Commons Attribution International License (CC BY 4.0).

http://creativecommons.org/licenses/by/4.0/

\begin{abstract}
Focusing on positive service experiences, this study examined the relationships among employee extra attention, customers delight, and customer repurchase intentions. The target sample that had a positive interaction with an employee in the recent six months was invited to participate in the survey. The data analysis was performed in two steps: 1) Confirmatory Factor Analysis (CFA) and 2) Structural Equation Modeling (SEM). The results suggested that employees' extra attention affects customer delight. Subsequently, customer delight has a positive relationship with customer repurchase intentions. Furthermore, employee extra attention has a positive relationship with customer repurchase intentions. The finding of the study provides valuable implications for research and the industry regarding generating favorable customer repurchase intentions in positive service experiences.
\end{abstract}

\section{Keywords}

Employee Extra Attention, Customer Delight, Customer Repurchase Intentions

\section{Introduction}

Customer-contact employees play an essential role in the interactions between customers and employees because employees' behaviors have an impact on customers' perception of service quality [1], customer satisfaction, loyalty, and behavioral intentions [2] [3] [4]. In the contexts of positive service experiences, employees' special attentions and little extras are frequently noted in positive memorable service experiences [5] [6]. Similar to employees' extra attention, unprompted and/or unsolicited employee behaviors which are unexpected from customers' point of view are one of the substantial source of customers' satisfactory service experience [5]. Those unusual employee behaviors such as "treating 
customers like royalty" make customers to remember that the service provider treats them in a unique way resulting in highly satisfactory and memorable positive service experience [5]. Employees' extra attentions refer to their behaviors and attitudes which are exemplary and unexpected by the customer [5]. This type of behavior is similar to "extra-role" service behaviors which are employees' discretionary services going beyond the prescribed role requirements [7].

Emotion is an important aspect in examining customers' service experiences [8]. In understanding the effect of employees' extra attentions on customer emotions, the current study adopts the discrete emotions approach rather than the valenced-based emotions approach. According to the valenced-based emotions approach, emotions are categorized into two types of emotions (i.e., positive and negative) [9]. However, existent research suggests that each discrete emotion within the same valence can result in distinct behavioral responses [10]. Research also suggests that the discrete emotions approach is more useful to examining particular behavioral responses [11]. Because delight is induced by unexpected positive outcomes [12], and customers usually do not expect employees' extra attentions, this study examines the effect of employee extra attention on customer delight.

Delight arises when customers experience unexpected positive outcomes [12]. Furthermore, emotions have an impact on numerous aspects of customer behaviors [13]. For example, customers who experience positive emotions are likely to come to repurchase with the company to enjoy the same positive experience [14]. Similarly, this study expects to find the impact of delight on repurchase intentions in positive service experiences. To fully understand the influence of employees' extra attentions on customers' responses, the relationship between employees' extra attention and customer repurchase intentions is examined in the study as well. Specifically, this study aims to investigate the impact of employee extra attention on customer delight and repurchase intentions and the relationship between customer delight and customer repurchase intentions.

The concept of employee extra attention has been discussed in past literature; however, the effect of this construct on customers' responses has not been empirically tested in the literature. This study attempts to examine the impact of employee extra attention on customer emotion of delight and customer behavioral intention of repurchase intentions. In addition, dissatisfying service experiences have been examined extensively in the past literature. This study adds to the limited research on the antecedents and consequences of positive services experiences through the investigation of customers' emotional and behavioral responses to employee extra attention. Practically, the findings of this study help the industry to understand the effect of employee extra attention on customer responses in positive service experiences. Managers can utilize those results to generate favorable customer responses through employee extra attentions.

The rest of the study is organized as below. First, a review related to employee extra attention, customer delight, and customer repurchase intentions is presented. Second, the hypotheses establishing the relationships among employee 
extra attention, customer delight, and customer repurchase intentions are introduced. Next, the methodology and the results of the hypotheses testing are discussed. Finally, the implications for both research and practice are summarized.

\section{Research Hypotheses}

\subsection{Employee Extra Attention and Customer Delight}

Employee extra attention refers to the extent to which the service provider provided extra attention in the interaction with the customer. Those employees' attitude and behavior of going out of the way for the customer tend to result in memorable and highly satisfactory experience for customers. Although those "little extras" are not the main components of service delivery, they function to enhance the core service delivery [5]. Customers frequently recall those positive service experiences when the employee treats them in a unique way irrespective of core service requirements [5]. Those employees' "extra treatment" provides the source of both satisfaction and service quality [5]. Researchers also suggest that it is essential for employees to constantly surprise customers with unexpected services, so the company can keep customers and increase customers' perceived service quality [5].

Delight has been considered as an extreme high level of satisfaction [15]. On the other hand, employees' behaviors of extra attentions exceeding customers' expectations in a positive manner can result in a highly satisfactory service experience [5]. Reference [5] also suggests that unprompted and/or unsolicited employee actions which are similar to employee extra attentions can result in customer delight [5]. In their study, reference [16] indicates that employees' behaviors of going outside of prescribed duty is one of the most frequently appearing sources of customer delight in customers' feedback in the hotel industry. From the customer's perspective, those employee behaviors of extra attention are in fact unexpected. Based on the discussions above, this study expects that:

H1: Employee extra attention has a positive effect on customer delight

\subsection{Employee Extra Attention and Customer Repurchase Intentions}

Customer repurchase intention is defined as customers' intent to stay with an organization [17]. Repurchase intentions refer to customers' commitment to purchase more products and services from the company [17] resulting in reduced customer acquisition costs, lower costs of serving repeat customers, increased revenue, and better profitability [18]. In marketing research, it is agreed that repeat patronage is a major behavioral outcome for measuring relationship marketing success [19].

Literature suggests that customers are inclined to re-patronage with the company if customers are satisfied with the firm [20]. On the other hand, it is implied that employee extra attentions of going out of the way for the customer tend to result in highly satisfactory service experiences for customers. Based on 
the discussions above, this study expects that:

H2: Employee extra attention has a positive effect on customer repurchase intentions

\subsection{Customer Delight and Repurchase Intentions}

Delight is viewed as an emotion with a mixture of joy and surprise in psychology literature [21] and is defined as "an extreme expression of positive affect resulting from surprisingly good performance" [22]. Based on the expectancy-disconfirmation theory, customers experience a positive disconfirmation when they perceive that the service they received exceeds their expectations for the product or service [23]. The expectancy-disconfirmation theory states that customers experience delight when they are pleasantly surprised in response to a positive disconfirmed experience toward a company or its product/service experiences [24]. Similarly, the tourists feel delight when they appraise their theme park experience as unexpected in the contexts of theme parks [25].

Recent literature suggests that customer delight is one of the antecedents of loyalty [26], which is defined as a strongly held commitment to consistently repurchase or re-patronize a preferred product or service in the future uninfluenced by situational impacts and marketing efforts of competitors to encourage potential switching behavior [22]. Furthermore, the broaden-and-build theory of positive emotions suggests that people who experience positive emotions are encouraged to approach or continued action and participate in the environment [27]. In consumption setting, customers' approaching, or continued action can be customers' behavior of repurchasing with the company. Based on the discussions above, this research hypothesizes that

H3: Customer delight has a positive effect on customer repurchase intentions.

Figure 1 summarizes the relationships among employee extra attention, customer delight, and customer repurchase intentions. Hypothesis 1 establishes the positive relationship between employee extra attention and customer delight, hypothesis 2 states the positive effect of employee extra attention on customer repurchase intentions, and hypothesis 3 implies the positive impact of customer delight on customer repurchase intentions.

\section{Methods}

\subsection{Procedures and Sample}

Customers who had a positive service experience in hotels is the target population

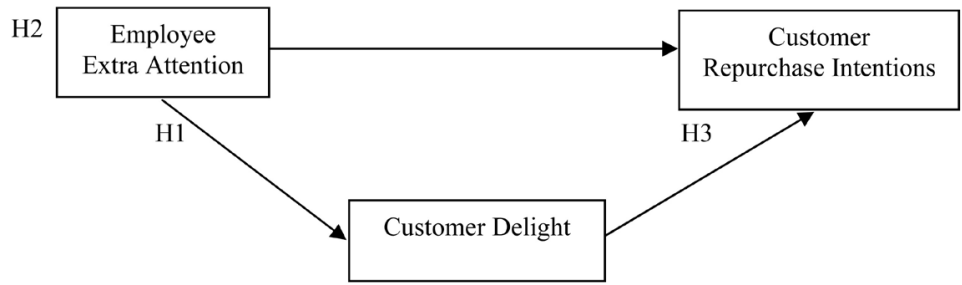

Figure 1. The conceptual framework of the study. 
of the study. The sampling frame consists of US adults who match the characteristic of target population in online marketplace Amazon Mechanical Turk. The target sample is US adults over 18 years old with a positive hotel experience with an employee in the last six months. The self-administrated online survey was sent to US adults who match the characteristic of target population in online marketplace Amazon Mechanical Turk which is an innovative and open online marketplace for data collection, task creation, labor recruitment, and compensation [28]. US adults over 18 years old with a positive hotel experience with an employee in the recent six months were screened and invited to participate in the study and asked to evaluate their most recent positive interaction with an employee at hotels.

\subsection{Instruments}

All the scale items were adapted from the relevant literature with minor wording modifications to reflect the study context. The items of employee extra attentions and customer repurchase behavioral intentions were measured by 7-point Likert scales ranging from strongly disagree (1) to strongly agree (7) while the items of customer delight were assessed ranging from not at all (1) to a lot (7) to indicate the level of the discrete emotion experienced.

Employee extra attention measures if the service provider offered special attention going beyond the prescribed role in the service encounter with three items "The employee paid special attention to me", "The employee went out of his/her way", "The employee gave me a break (something extra)" adapted from [6]. Customer delight was measured with three items "gleeful", "elevated", and "delighted" adapted from [29]. Customer repurchase intentions were assessed with two items from [30]. "I would visit this hotel again" and "I would go to this hotel more often" and one item from [31] "I am more likely to return to this hotel next time."

\subsection{Statistical Analyses}

A structural equation modeling technique (SEM) was utilized to test the hypotheses of the study. Before proceeding to further analysis, the assumptions of statistical procedures (e.g., normality, homogeneity) procedures were validated and potential issues of missing data and outliers were assessed. A SEM analysis was conducted using a two-phase approach [32] with the first phase of confirmatory factor analysis to evaluate the adequacy of the measurement model to ensure construct reliability and validity and the second phase of the structural model assessing the proposed hypotheses with goodness-of-fit indices.

\section{Results}

\subsection{Profile of Respondents}

A total of 349 responses were collected and 302 usable responses were retained for the data analysis after screening the data for filter question, attention check, 
and missing data. The respondents consisted of $44.7 \%$ males and $54.6 \%$ of females with most of the group age between 26 and 35 years old (41.1\%) followed by 18 - 25 (19.9\%) and between 36 - 45 (18.2\%). For the marital status, $42.1 \%$ are married followed by single (31.8\%) and partnered (15.2\%). For the ethnic background, the majority of the sample are Caucasian (78.5\%) followed by African American (7.9\%), Asian/Island Pacific (6.3\%) and Hispanic (6.3\%). The summary of respondents' background is presented in Table 1.

\subsection{Construct Reliability and Validity}

Construct reliability was examined with inter-item reliability (Cronbach's Alpha) and scale composite reliability (SCR). The values of Cronbach's alpha and composite reliabilities of the constructs are above 0.7 , revealing acceptable internal consistency for the constructs. The convergent validity was assessed through average variance extracted (AVE), standardized factor loadings, and the comparison between average variance extracted (AVE) and composite reliability

Table 1. Profile of respondents.

\begin{tabular}{|c|c|c|}
\hline Demographic Variables & Frequency & Valid percentage \\
\hline \multicolumn{3}{|l|}{ Gender } \\
\hline Male & 135 & 44.7 \\
\hline Female & 165 & 54.6 \\
\hline \multicolumn{3}{|l|}{ Age } \\
\hline $18-25$ & 60 & 19.9 \\
\hline $26-35$ & 124 & 41.1 \\
\hline $36-45$ & 55 & 18.2 \\
\hline $46-55$ & 42 & 13.9 \\
\hline $56-65$ & 16 & 5.3 \\
\hline$>65$ & 5 & 1.7 \\
\hline \multicolumn{3}{|l|}{ Marital Status } \\
\hline Married & 127 & 42.1 \\
\hline Partnered & 46 & 15.2 \\
\hline Separated/Divorced & 28 & 9.3 \\
\hline Widowed & 3 & 1 \\
\hline Single & 96 & 31.8 \\
\hline \multicolumn{3}{|l|}{ Ethnicity } \\
\hline Caucasian & 237 & 78.5 \\
\hline Asian/Island Pacific & 19 & 6.3 \\
\hline African American & 24 & 7.9 \\
\hline Hispanic & 19 & 6.3 \\
\hline American Indian/other & 3 & 1 \\
\hline
\end{tabular}


(CR). The results indicated that the values for AVE exceed 0.5 best value and CR values are higher than AVE values. Moreover, the standardized factor loadings indicated significant values at the 0.001 level, and the item loadings are greater than the recommended 0.5. The examination revealed an adequate convergent validity for each construct in the measurement instrument. Examining factor correlations and the square root of AVE suggested no discriminant validity issues in the measurement model. The results suggested that convergent and discriminant validity of the measurement model have been met. Therefore, a theoretically satisfactory model was achieved in the first phase of data analysis.

\subsection{Structural Equation Modeling}

SEM was run to investigate the causal relationships of the constructs included in the theoretical framework. From the obtained results of the Absolute Fit Measures, the index for Goodness-of-fit Index (GFI) is 0.893 exceeding the desired 0.85 . From the results of the incremental fit measures, the value for Normed Fit Index (NFI) is 0.902 which is higher than desired threshold 0.9. Finally, from the results of the parsimonious fit measures, the value for Parsimony Normed Fit Index (PNFI) is 0.697 meeting the minimum expected criteria 0.5 . Therefore, the goodness-of-fit statistics suggested that the structural equation model fit is adequate. The next section discusses the hypotheses testing and results.

\subsection{Hypotheses Testing Results}

H1: Employee extra attention has a positive effect on customer delight.

The first proposed hypothesis predicted that employees' extra attention increases customer delight. The findings related to $\mathrm{H} 1$ (path coefficient $=0.45, \mathrm{p}<$ 0.001 ) suggested that employees' extra attention has a positive influence on customer delight.

H2: Employee extra attention has a positive effect on customer repurchase intention.

The second hypothesis predicted that employees' extra attention increases customer repurchase intentions. Results from the present study suggested that employee extra attention has a significant influence on customer repurchase intentions (path coefficient $=0.41, \mathrm{p}<0.001$ ).

H3: Customer delight has a positive effect on customer repurchase intention.

The third proposed hypothesis predicted that customer delight increases customer repurchase intentions. The findings related to $\mathrm{H} 3$ (path coefficient $=0.21$, $\mathrm{p}<0.001)$ suggested that customer delight has a positive influence on customer repurchase intentions.

In summary, the results of the hypotheses testing indicated that employees' extra attentions positively affect both customer delight and customer repurchase intentions. Furthermore, customer delight has a positive impact on customer repurchase intentions. Therefore, it is indicated that employee extra attention triggers both customer delight and customer repurchase intentions. In addition, 
customers who feel delight in positive service experiences tend to come back to repurchase with the company.

\section{Discussions}

Consistent with what has been suggested in the past literature, the results of the study identify the importance of employees' extra attentions to trigger customer delight which in turn affects customers' repeat purchase. In addition, the direct relationship between employees' extra attention and customer repurchase intentions is established as well. Aligning with existing literature, employees' behavior of going beyond specified in-role behaviors to exceed customers' expectations serves as a strong antecedent of customer delight [5]. This research suggested that the service provider's extra attention in a positive manner resulted in customer feeling of pleasant surprise (delight) [24]. In addition, the effect of delight on customers repurchase intentions has been supported. As indicated in the results, the experience of delight triggers customer to visit the company more often. This finding also confirmed that customers tend to exhibit approach behaviors to prolong the pleasant feeling [27]. Theoretically, the current study found out that the theory of positive emotions can be applicable in the setting of positive service encounters. Furthermore, the study also found out that how customers' favorable behaviors of repeat purchases can be induced through the feeling of delight and employee behaviors of extra attention. The current study provides practical implications for practitioners regarding how to generate favorable customer behaviors of repeat purchase. For theoretical implication, the study offers a deeper understanding of post-purchase customer behaviors from a consumption emotion perspective. Besides the theoretical contribution to the literature, the current study advances limited positive service encounter literature by providing a deeper understanding of the effect of employee extra attention on customer delight and customer repurchase intentions with empirical evidence.

For the business, it is essential to gain a better understanding of positive service encounters because the interaction between the contact employee and the customer influences customers' perception regarding the service and the firm. Moreover, those customers' perceptions affect customers' subsequent actions after the service experience. The findings of the study can provide some insights into how the practitioners can take advantage of employees' extra attention during their interaction with the customers to generate favorable customers' behaviors which would help the performance of the company.

The results of the study also identified the importance of employees' extra attention to trigger customer delight which in turn affects customers' repeat purchase. Consistent with what has been suggested in the past literature, it is essential for employees to constantly surprise customers with unexpected service in order to retain customers [5]. Therefore, employees should be encouraged to go beyond the specified responsibilities and to find creative ways to provide something extra in addition to the regular service offering. The service company is suggested to empower their employees to enable them to deliver the service 
beyond the standard procedures. For example, the employees at the Ritz-Carlton have up to $\$ 2000$ to make unsatisfied guests happy again without the approval from upper management. Also, employees need to be innovative and creative in order to be able to think of diversified strategies in their service delivery. Brainstorming or inspiring true stories of excellent service delivery can be utilized in the staff meeting to stimulate employees' creativity.

\section{Conclusions}

Focusing on positive service experiences, this study examined the relationships among employee extra attention, customers delight, and customer repurchase intentions. The results suggested that employees' extra attention affects customer delight which in turn affects customer repurchase intentions. Furthermore, employee extra attention has a positive relationship with customer repurchase intentions.

Although the current study offers significant theatrical and practical knowledge, some limitations existed in the study. First of all, the results of the study might not be able to be generalized to the population which is not similar with the sample of the study. The sample was collected in the United States and the majority of the samples were Caucasians. Future studies with diversified cultures are needed in order to confirm the external validity of the proposed theoretical framework.

Methodologically, the study employed survey research which asked the respondents to recall their most recent positive service experience and assessed that particular experience. The design of the study might have limitations of gathering customers' true responses in the service encounters because of the time lag between the time when the experience occurred and the time when the respondents fill out the survey. Future studies are encouraged to apply different methodology to empirically examine the proposed model in the study.

Based on the results of the study, it is indicated that employee extra attentions play an important role in generating favorable customers' responses after a positive service experience. However, it is not clear that why employees display extra attention in their interactions with the customer. In order to understand the motivations behind employee extra attention, future studies can be conducted to examine the antecedents of employee extra attention. For the business, the findings of the study can provide some practical implications for employee recruiting and training and company policies.

\section{Conflicts of Interest}

The authors declare no conflicts of interest regarding the publication of this paper.

\section{References}

[1] Farrell, A., Souchon, A. and Durden, G. (2001) Service Encounter Conceptualiza- 
tion: Employees' Service Behaviors and Customers' Service Quality Perceptions. Journal of Marketing Management, 17, 577-593. https://doi.org/10.1362/026725701323366944

[2] Hartline, M.D. and Jones, K.C. (1996) Employee Performance Cues in a Hotel Service Environment: Influence on Perceived Service Quality, Value, and Word-of-Mouth Intentions. Journal of Business Research, 35, 207-215. https://doi.org/10.1016/0148-2963(95)00126-3

[3] Hennig-Thurau, T. (2004) Customer Orientation of Service Employees: Its Impact on Customer Satisfaction, Commitment, and Retention. International Journal of Service Industry Management, 15, 460-478. https://doi.org/10.1108/09564230410564939

[4] Salanova, M., Agut, S. and Peiró, J. M. (2005) Linking Organizational Resources and Work Engagement to Employee Performance and Customer Loyalty: The Mediation of Service Climate. Journal of Applied Psychology, 90, 1217. https://doi.org/10.1037/0021-9010.90.6.1217

[5] Bitner, M.J., Booms, B.H. and Tetreault, M.S. (1990) The Service Encounter: Diagnosing Favorable and Unfavorable Incidents. The Journal of Marketing, 54, 71-84. https://doi.org/10.2307/1252174

[6] Price, L.L., Arnould, E.J. and Deibler, S.L. (1995) Consumers' Emotional Responses to Service Encounters: The Influence of the Service Provider. International Journal of Service Industry Management, 6, 34-63. https://doi.org/10.1108/09564239510091330

[7] Bettencourt, L.A. and Brown, S.W. (1997) Contact Employee: Relationships among Workplace Fairness, Job Satisfaction and Prosocial Service Behaviors. Journal of Retailing, 73, 39-61. https://doi.org/10.1016/S0022-4359(97)90014-2

[8] Nyer, P. (1997) A Study of the Relationships between Cognitive Appraisals and Consumption Emotions. Journal of the Academy of Marketing Science, 25, 296-304. https://doi.org/10.1177/0092070397254002

[9] Hooge, I.E., Verlegh, P.W. and Tzioti, S.C. (2014) Emotions in Advice Taking: The Roles of Agency and Valence. Journal of Behavioral Decision Making, 27, 246-258. https://doi.org/10.1002/bdm.1801

[10] Laros, F.J. and Steenkamp, J.B.E. (2005) Emotions in Consumer Behavior: A Hierarchical Approach. Journal of Business Research, 58, 1437-1445. https://doi.org/10.1016/j.jbusres.2003.09.013

[11] Mattila, A.S. and Ro, H. (2008) Discrete Negative Emotions and Customer Dissatisfaction Responses in a Casual Restaurant Setting. Journal of Hospitality Tourism Research, 32, 89-107. https://doi.org/10.1177/1096348007309570

[12] Bitner, M.J., Brown, S.W. and Meuter, M.L. (2000) Technology Infusion in Service Encounters. Journal of the Academy of Marketing Science, 28, 138-149. https://doi.org/10.1177/0092070300281013

[13] Gardner, M.P. (1985) Mood States and Consumer Behavior: A Critical Review. Journal of Consumer Research, 12, 281-300. https://doi.org/10.1086/208516

[14] Tsai, W.C. and Huang, Y.M. (2002) Mechanisms Linking Employee Affective Delivery and Customer Behavioral intentions. Journal of Applied Psychology, 87, 1001-1008. https://doi.org/10.1037/0021-9010.87.5.1001

[15] Alexander, M.W. (2010) Customer Delight: A Review. Academy of Marketing Studies Journal, 14, 39-54.

[16] Torres, E.N. and Kline, S. (2013) From Customer Satisfaction to Customer Delight: 
Creating a New Standard of Service for the Hotel Industry. International Journal of Contemporary Hospitality Management, 25, 642-659. https://doi.org/10.1108/IJCHM-Dec-2011-0228

[17] Khan, M.S., Naumann, E. and Williams, P. (2012) Identifying the Key Drivers of Customer Satisfaction and Repurchase Intentions: An Empirical Investigation of Japanese B2B Services. Journal of Consumer Satisfaction, D Is satisfaction \& Complaining Behavior, 25, 159-178.

[18] Ganesh, J., Arnold, M.J. and Reynolds, K.E. (2000) Understanding the Customer Base of Service Providers: An Examination of the Differences between Switcher and Stayers. Journal of Marketing, 64, 65-87. https://doi.org/10.1509/jmkg.64.3.65.18028

[19] Reichheld, F. (1996) The Loyalty Effect. Harvard Business School Press, Boston.

[20] Schneider, B. and Bowen, D.E. (1999) Understanding Customer Delight and Outrage. Sloan Management Review, 41, 35-45.

[21] Plutchik, R. (1980) A General Psychoevolutionary Theory of Emotion. In: Plutchik, Ed., Theories of Emotion, Elsevier Inc., Atlanta, 3-33. https://doi.org/10.1016/B978-0-12-558701-3.50007-7

[22] Oliver, R.L., Rust, R.T. and Varki, S. (1997) Customer Delight: Foundations, Findings, and Managerial Insight. Journal of Retailing, 73, 311-336.

https://doi.org/10.1016/S0022-4359(97)90021-X

[23] Oliver, R.L. (1981) Measurement and Evaluation of Satisfaction Processes in Retailing Setting. Journal of Retailing, 57, 25-48.

[24] Crotts, J.C., Pan, B. and Raschid, A.E. (2008) Research in Brief: A Survey Method for Identifying Key Drivers of Guest Delight. International Journal of Contemporary Hospitality Management, 20, 462-470.

https://doi.org/10.1108/09596110810873552

[25] Ma, J., Gao, J., Scott, N. and Ding, P. (2013) Customer Delight from Theme Park Experiences: The Antecedents of Delight Based on Cognitive Appraisal Theory. Annals of Tourism Research, 42, 359-381. https://doi.org/10.1016/j.annals.2013.02.018

[26] Kim, M., Vogt, C.A. and Knutson, B.J. (2015) Relationships among Customer Satisfaction, Delight, and Loyalty in the Hospitality Industry. Journal of Hospitality \& Tourism Research, 39, 170-197. https://doi.org/10.1177/1096348012471376

[27] Fredrickson, B.L. (2001) The Role of Positive Emotions in Positive Psychology: The Broaden-and-Build Theory of Positive Emotions. American Psychologist, 56, 218-226. https://doi.org/10.1037/0003-066X.56.3.218

[28] Buhrmester, M., Kwang, T. and Gosling, S.D. (2011) Amazon's Mechanica Turk a New Source of Inexpensive, Yet High-Quality, Data? Perspectives on Psychological Science, 6, 3-5. https://doi.org/10.1177/1745691610393980

[29] Finn, A. (2005) Reassessing the Foundations of Customer Delight. Journal of Service Research, 8, 103-116. https://doi.org/10.1177/1094670505279340

[30] Smith, A.K. and Bolton, R.N. (1998) An Experimental Investigation of Customer Reactions to Service Failure and Recovery Encounters: Paradox or Peril? Journal of Service Research, 1, 65-81. https://doi.org/10.1177/109467059800100106

[31] Anderson, E.W. (1994) Cross-Category Variation in Customer Satisfaction and Retention. Marketing Letters, 5, 19-30. https://doi.org/10.1007/BF00993955

[32] Anderson, J.C. and Gerbing, D.W. (1988) Structural Equation Modeling in Practice: A Review and Recommended Two-Step Approach. Psychological Bulletin, 103, 411-423. https://doi.org/10.1037/0033-2909.103.3.411 